\title{
EMPLOYMENT AND UNEMPLOYMENT AS PREDICTORS OF ECONOMIC SECURITY ON THE EXAMPLE OF THE REPUBLIC OF BULGARIA
}

\author{
Elitsa PETROVA, Stefan FILIPOV \\ "Vasil Levski" National Military University, Veliko Tarnovo, Bulgaria \\ elitsasd@abv.bg*, stefan_filip@abv.bg**
}

\begin{abstract}
The article presents employment and unemployment as predictors of economic security in the context of a social challenge facing the national security on the example of the Republic of Bulgaria. Any decline and negative trends associated with these indicators such as low employment, non-participation of full labor potential in the public production, high unemployment, low minimum and average wages, low labor quality inevitably lead to undermining economic security of the state. The article pays special attention to the level of employment in the economy of the Republic of Bulgaria; the average monthly salary of the employees under labor and employment relationship; the average number of employed persons under labor and employment relationship; the unemployed persons and unemployment coefficients of the population by age, sex, duration of unemployment, ways of looking for work, and unemployment by statistical zones and regions in the Republic of Bulgaria. An analysis is made of the average annual salary of the employees under employment and service relationship.
\end{abstract}

\section{Keywords: employment, unemployment, economic security}

\section{Introduction}

The main task of the state is to guarantee a certain level of economic security by predicting and eliminating the emergence and development of various threats with the help of its macroeconomic levers and means of impact. The increasing negative effects of certain regarded economic security economic indicators lead to various losses for the state. $[3,4,5]$ In a broad sense, employment encompasses all persons who engage in community service, regardless of whether they receive remuneration in any form. It is measured by the ratio of the employed in companies, households and personal economy to the population at working age, and the number of students. In a narrow sense, employment encompasses only those people who, against labor receive remuneration in the form of wages to the entire population. According to some authors it is mainly aware of the real financial results and the possibility of specialization of the staff. $[1,6,7]$

Unemployment is a concept that encompasses all persons who are not actively employed but are looking for a job or expecting to return to work again. The absolute rate of unemployment is determined by people without a job, who have expressed their desire to work through their employment in the labor offices. The unemployment rate is calculated by dividing the unemployed by the workingage population or by taking the unemployed into the workforce. Its natural level is formed by the percentage of unemployed, which is conditioned by causes outside the cycle and covers the current and structural, but excludes cyclical unemployment. It is 
always greater than zero. Unemployment ranges from $5-7 \%$ are at a natural level.

\section{Employment and unemployment in the Republic of Bulgaria}

The official employment data for the economy of the Republic of Bulgaria in 2016 shows that 3463347 persons were employed, of which 887266 persons are self-employed. The average monthly salary of employees in labor and service contracts in Bulgaria ranges from BGN 995 or EUR 508.73 in January 2017 and reaches a level of BGN 1064 or EUR 541.70 in January 2017 in September 2017. Despite the observed increasing in the average wage, the prices of products and services in the country are quite similar to European's; therefore it can be hardly accounted for a positive trend. The level of income significantly determines the standard of living of the population, which is the main factor in the reproduction of labor resources. The living standard is the basis for the formation of such indicators as the level of health, education and qualifications that are crucial to the competitiveness of national production and national economy.

Table 1 Average Monthly Salary of Employed Persons under Labor and Service Relationship in 2017 in the Republic of Bulgaria - total (BGN)

\begin{tabular}{|l|l|l|l|l|l|l|l|l|l|}
\hline & \multicolumn{8}{|c|}{ Months } \\
\hline T & II & III & IV & V & VI & VII & VIII & IX \\
\hline Total & 995 & 987 & $\mathbf{1 0 3 6}$ & $\mathbf{1 0 6 0}$ & $\mathbf{1 0 3 5}$ & $\mathbf{1 0 2 7}$ & $\mathbf{1 0 3 9}$ & $\mathbf{1 0 0 8}$ & $\mathbf{1 0 6 4}$ \\
\hline
\end{tabular}

Source: http://www.nsi.bg/bg

Table 2 Average Monthly Salary of Employees by forms of ownership 2017, the Republic of Bulgaria (BGN)

\begin{tabular}{|l|r|r|r|r|r|r|r|r|r|}
\hline \multirow{2}{*}{ Form of ownership } & \multicolumn{10}{|c|}{ Months } \\
\cline { 2 - 9 } & I & II & III & IV & V & VI & VII & VIII & IX \\
\hline Public sector & 1019 & 970 & 1023 & 1088 & 1041 & 1034 & 1076 & 992 & 1081 \\
\hline Private sector & 987 & 992 & 1040 & 1051 & 1033 & 1025 & 1027 & 1012 & 1059 \\
\hline
\end{tabular}

Source: http://www.nsi.bg/bg

The current survey shows an average monthly salary for employed persons under labor and service contracts by forms of ownership in the Republic of Bulgaria in 2017. The data do not reveal significant pay gap in the public and private sector. The linear forecasting trend of the average monthly salary of the employed under the labor contract by forms of ownership shows a trend of increase in salary in 2017, which can be regarded as positive for the economy of the state. 


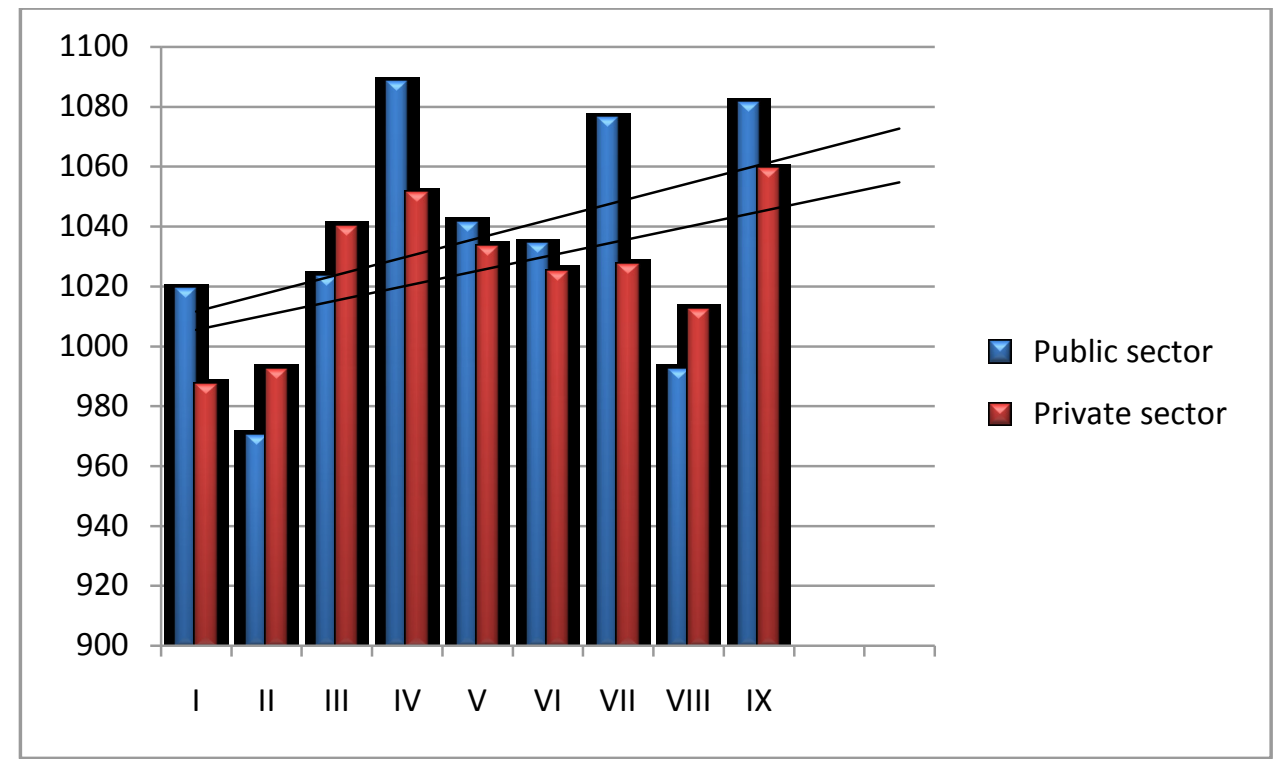

Figure 1: Monthly salary of employees under labor contract in 2017 in the Republic of Bulgaria (BGN) /linear forecasting trend/

The analysis of the average monthly salary of employed persons under labor and service contracts in the year 2017 in the Republic of Bulgaria shows that it is increasing at a slow pace. A more significant increase is recorded in the private sector.

Table 3 Average Annual Salary of Employees under Employment and Service Relationship in the Republic of Bulgaria, 2010-2016 (BGN)

\begin{tabular}{|c|c|c|c|}
\hline Year & Total & Public sector & $\begin{array}{l}\text { Private } \\
\text { sector }\end{array}$ \\
\hline 2010 & 7777 & 8983 & 7366 \\
\hline 2011 & 8230 & 9133 & 7926 \\
\hline 2012 & 8773 & 9784 & 7772 \\
\hline 2013 & 9301 & 10027 & 9054 \\
\hline 2014 & 9860 & 10654 & 9602 \\
\hline 2015 & 10535 & 11109 & 10355 \\
\hline 2016 & 11539 & 11818 & 11450 \\
\hline
\end{tabular}

Source: http://www.nsi.bg/bg

The average annual salary in Bulgaria for the surveyed period increases from BGN 7777 to BGN 11539 or from EUR 3977.47 to EUR 5894.95, which is a favorable but insufficient trend that is directly related to the potential to improve household consumption and living standards. It is necessary to make a note that, in order to assess the extent to which such an increase should also result in an increase in the purchasing power of households, other factors such as gross domestic product, inflation and inflation rates, investment activity, government debt, etc. have to be taken into account. 
Table 4 Unemployed persons and unemployment rates of the population aged 15 and over in the Republic of Bulgaria, the third quarter of 2017

\begin{tabular}{|c|c|c|}
\hline $\begin{array}{c}\text { Gender } \\
\text { Place of residence } \\
\text { Degrees of education } \\
\text { Age }\end{array}$ & $\begin{array}{l}\text { Unemployed } \\
\text { persons } \\
\text { thousand }\end{array}$ & $\begin{array}{c}\text { Unemployment } \\
\text { ratios } \\
\%\end{array}$ \\
\hline Total & 200.2 & 5.8 \\
\hline \multicolumn{3}{|l|}{ By gender } \\
\hline Men & 112.4 & 6.1 \\
\hline Women & 87.8 & 5.5 \\
\hline \multicolumn{3}{|l|}{ By place of residence } \\
\hline \begin{tabular}{|l|} 
in the cities \\
\end{tabular} & 134.8 & 5.1 \\
\hline In the villages & 65.4 & 8.5 \\
\hline \multicolumn{3}{|l|}{ By age } \\
\hline $15-24$ & 26.3 & 13.9 \\
\hline $25-34$ & 51.2 & 6.8 \\
\hline $35-44$ & 46.6 & 5.0 \\
\hline $45-54$ & 40.5 & 4.8 \\
\hline 55 and over & 35.5 & 5.0 \\
\hline \multicolumn{3}{|l|}{ By degrees of education } \\
\hline High & 35.2 & 3.4 \\
\hline Average & 99.6 & 5.1 \\
\hline $\begin{array}{l}\text { including with acquired professional } \\
\text { qualification }\end{array}$ & 60.7 & 5.2 \\
\hline Basically & 48.8 & 13.3 \\
\hline Initial and lower & 16.5 & 24.1 \\
\hline
\end{tabular}

Source: http://www.nsi.bg/bg

When examining the unemployment rate for the population aged 15 and over in the Republic of Bulgaria in the third quarter of 2017, it can be found the following: higher unemployment rate for men compared to women, higher unemployment rate in villages vs. towns, high unemployment rate for young people aged 15-34 compared to those aged 35-55 and over. The highest unemployment rate is found in people with primary or lower education.

Critical values of unemployment in economic theory are set at the order of 15
$\%$. It is believed that when reaching this limit, society is on the verge of the social blast, which is a direct threat to economic security. According to official data, the unemployment rate for the population aged 15 and over in the Republic of Bulgaria in the third quarter of 2017 is $5.8 \%$, which can be considered as a normal level. Below is a detailed analysis of the unemployed in terms of job search, gender, age, and by statistical zones and regions. 
Table 5 Unemployed People Looking for Job in the Republic of Bulgaria,the third quarter of 2017 /thousands/

\begin{tabular}{|l|l|l|l|}
\hline \multicolumn{1}{|c|}{ Ways to Search for a Job $^{1}$} & \multicolumn{1}{|c|}{ Total } & \multicolumn{1}{|c|}{ Men } & Women \\
\hline Total & 200.2 & 112.4 & 87.8 \\
\hline of them were looking for a job by: & 73.1 & 36.8 & 36.3 \\
\hline Contact with State Labor Offices & 102.3 & 61.6 & 40.6 \\
\hline Establish a direct relationship with employers & 30.1 & 15.2 & 14.9 \\
\hline Participation in competitions, exams or interviews & 143.6 & 80.9 & 62.7 \\
\hline Search for help from relatives and acquaintances & 50.9 & 28.0 & 22.8 \\
\hline Giving or answering job ads & 48.8 & 39.0 \\
\hline Study job advertisements in newspapers, magazines and more & 87.8 & \\
\hline${ }^{1}$ Job search is indicated in more than one way by one person.
\end{tabular}

Source: http://www.nsi.bg/bg

Table 7 Unemployed Persons by Duration of Unemployment and Gender in the Republic of Bulgaria, the third quarter of 2017 in thousands

\begin{tabular}{|l|l|l|l|}
\hline \multicolumn{1}{|c|}{ Duration of unemployment } & \multicolumn{1}{c|}{ Total } & \multicolumn{1}{c|}{ Men } & Women \\
\hline Total & 200.2 & 112.4 & 87.8 \\
\hline Up to 5 months & 54.6 & 32.2 & 22.4 \\
\hline $6-11$ months & 36.0 & 20.6 & 15.4 \\
\hline $12-23$ months & 34.2 & 19.5 & 14.7 \\
\hline 2 years and over & 75.4 & 40.1 & 35.3 \\
\hline
\end{tabular}

Source: http://www.nsi.bg/bg

Table 8 Unemployed Persons and Unemployment Rates of the Population aged 15 and over by Statistical Zones and regions in the Republic of Bulgaria, the third quarter of 2017

\begin{tabular}{|c|c|c|c|c|c|c|}
\hline \multirow{2}{*}{$\begin{array}{l}\text { Statistical zones } \\
\text { Statistical regions }\end{array}$} & \multicolumn{3}{|c|}{$\begin{array}{c}\text { Unemployed persons - } \\
\text { thousand. }\end{array}$} & \multicolumn{3}{|c|}{ Unemployment ratios - $\%$} \\
\hline & $\begin{array}{c}\text { in } \\
\text { general }\end{array}$ & men & women & $\begin{array}{c}\text { in } \\
\text { general }\end{array}$ & men & women \\
\hline Total & 200.2 & 112.4 & 87.8 & 5.8 & 6.1 & 5.5 \\
\hline \multicolumn{7}{|c|}{ Northern and Southeastern Bulgaria } \\
\hline Northwestern & 33.7 & 18.4 & 15.2 & 10.8 & 10.9 & 10.7 \\
\hline Northern Central & 23.3 & 14.4 & 8.9 & 6.4 & 7.2 & 5.4 \\
\hline Northeastern & 44.4 & 22.2 & 22.2 & 9.5 & 8.8 & 10.3 \\
\hline Southeastern & 27.6 & 16.8 & 10.8 & 5.6 & 6.3 & 4.8 \\
\hline \multicolumn{7}{|c|}{ Southwestern and Southern Central Bulgaria } \\
\hline Southwestern & 36.3 & 19.6 & 16.7 & 3.3 & 3.5 & 3.1 \\
\hline Southern central Bulgaria & 35.0 & 21.0 & 14.0 & 5.1 & 5.6 & 4.5 \\
\hline
\end{tabular}

Source: http://www.nsi.bg/bg

The population of Bulgaria is 7153784 people, according to official estimates, and 3463347 people or $48 \%$ of the total population in the labor market. The most used ways of looking for a job are: to establish a direct relationship with 
employers, seek assistance from relatives and acquaintances, and study job advertisements in newspapers, magazines and others. Regional data shows the highest unemployment rate in the Northeast region of Bulgaria. At the same time, the country's population is declining and aging. The average age of the population is also rising. The multiplication of negative social effects generates major threats to economic and social security. The official data show that than the men's unemployment rate is higher than women's, the unemployment is high among young people up to the age of 35, and the unemployment over 2 years is significant.

\section{Conclusion}

It could be made some important conclusions.

Official statistics show a normal level of employment and unemployment, trends in wage increases in both the private and the public sector are rising, the minimum and average salary increases, which could be a prerequisite for a rise in the economy. Although there are positive trends, there are also some social challenges related to these trends, which are particularly important for a country's defence and security policy. Undoubtedly, the relationship economy economic security - national security international security cannot be denied either theoretically or practically. A stable economy provides a basis for a stable state. The economic potential of a country is directly related to pursuing a policy of creating new jobs, increasing labor productivity, balancing energy and materials consumption, technological innovation, maintaining and updating the production base, and taking action to create an environment for attracting investment and stimulating domestic consumption as well as increasing exports of goods and services.

A key feature of the economic system, that determines its ability to ensure normal living and working conditions for the population, is to guarantee and protect the sustainable development of the economy and the realization of national economic interests. Effective management of market mechanisms and limiting the influence of the black economy are important predictors of economic development.

\section{References}

[1] Filipov, S., Contemporary Trends on the Labor Market in Bulgaria, New knowledge Journal of science, Academic Publishing House Talent, University of Agribusiness and Rural Development - Bulgaria, 2016, pp.15-22.

[2] http://www.nsi.bg/bg

[3] Petrova, E., Dimitrova, S., Sustainable development and national security, Spiru Haret University, Romania, Brasov, Scientific Journal Review of General Management, Volume 13, Issue 1, 2011, pp. $44 \div 54$.

[4] Petrova, E., Nichev, N., Impact of war on the economy, International Conference The Knowledge-Based Organization, Nicolae Balcescu Land Forces Academy, Sibiu, Romania, 2012, pp. $233 \div 236$.

[5] Petrova, E., Nichev, N., Main threats facing the development of a more secured world, Bulgarian Science Scientific Journal, Bulgaria. 48/2012, 9 p.

[6] Varbanova, B., Vicious circle of subsidized employment, International Conference Knowledge-Based Organization, Land Forces Academy "Nicolae Balcescu" SibiuRomania, pp. 339-343.

[7] Stefanov, N., Analysis of the Use of Outsourcing Services for Maintenance and Repair of the Equipment and Armament Available in the Structures of the Bulgarian Armed Forces. International conference Knowledge-Based Organization, Volume XXIII No 1, 2017, pp. 467-472. 